\title{
Annelerin İstismar Potansiyellerinin Bazı Değişkenler Açısından İncelenmesi
}

\author{
Serpil PEKDOĞAN ${ }^{1}$
}

Geliş Tarihi: 11.07.2016

Kabul Tarihi: 23.11.2016

Öz

Günümüzde çocuk istismarı yoğun bir şekilde devam etmektedir. Çeşitli sosyoekonomik ve eğitim düzeyindeki yetişkinlerin, çocuklara çeşitli istismar türlerini uyguladıkları bilgisi çeşitli kaynaklardan edinilmektedir. Alan yazın incelendiğinde ise çocuk istismarı ile ilgili birçok çalışma yapıldı ğ görülmektedir. Öğretmenlerin çocuk istismarı konusundaki farkındalık düzeyleri, aile içi istismar, istismarın çocuk üzerindeki etkileri yapılan çalışmalardan bazılarıdır. Bu çalışmada ise 4-6 yaş aralığında çocuğa sahip annelerin istismar potansiyellerinin bazı değişkenlerle olan ilişkisini incelemek amaçlanmıştır. Araştırma grubunu 235 anne oluşturmaktadır. Katılımcıların istismar potansiyellerini ölçmek için "İstismar Farkındalık Ölçeği-Ebeveyn Formu" kullanılmıştır. Araştırmanın katılımcılarının belirlenmesinde tipik durum örneklemesi yöntemi kullanılmıştır. Verilerin analizinde, korelasyon ve çoklu regresyon analizi kullanılmıştır. Korelasyon sonuçlarına göre istismar potansiyeli ile annelerin yaşı, çalışma durumları ve çocukların cinsiyetleri arasında, $\mathrm{p}<.05$ düzeyinde anlamlı ilişki olduğu saptanmıştır. Çoklu regresyon analizi sonuçları da annelerin yaşı ve çalışma durumlarının istismar potansiyelinin yordayıcısı olduğunu göstermiştir. Bulgular doğrultusunda çeşitli önerilerde bulunulmuştur.

Anahtar sözcükler: İstismar, anne, çocuk, okul öncesi.

\footnotetext{
${ }^{1}$ Yrd. Doç. Dr., Amasya Üniversitesi, Okul Öncesi Eğitimi Bölümü, serpil4423@hotmail.com
} 


\title{
Investigation of Mothers' Abuse Potentials According to Some Variables
}

\begin{abstract}
Child abuse continues intensively, nowadays. According to the different sources, it can be said that children are abused by the adults from every levels of socio-economic and educational status. There are many related studies in recent researches such as teachers' awareness levels of child abuse, domestic violence and the effects of abuse on children. The aim of this study is to investigate the relations between mothers' abuse potential who have 4-6 aged child. 235 mothers participated to this study. "Abuse Awareness Scala-Parent Form" was used in order to assess the participants' potentials of abuse. Maximum variation sampling method was used to determine the participants. Correlation and Multiple Regression Analysis were performed to analyze the data. According to the results there are significant correlations between the potential of abuse and age of mother, employment status, gender of children ( $\mathrm{p}<$ .05). According to the Multiple Regression results, age of mother and employment status predict the potential of abuse. Some suggestions were made according to these results.

Keywords: Abuse, mother, child, preschool.
\end{abstract}




\section{Giriş}

Toplumun en küçük birimi olan ailenin, insan yaşamı üzerindeki etkisi doğum öncesi dönemde başlamakta ve yaşam boyunca etkisini sürdürmektedir. Aile fizyolojik olduğu kadar, toplumsal ve ekonomik yönleriyle de çocuğa şekil vermekte ve çocuğun kişilik gelişiminde önemli bir rol oynamaktadır (Zeybekoğlu Dündar, 2012). Aile çocuğun beslenme, bakım ve korunma gibi ihtiyaçlarının yanı sıra duygusal ihtiyaçlarını da gidermekte önemli bir toplumsal birimdir (Tunca, 2012). Çocuğun aile içerisinde kurduğu iletişim, bütün gelişim alanlarını etkilemekte ve toplumla uyumlu olmasında önemli bir rol oynamaktadır. Sevgi ve güven gibi duygusal ihtiyaçlarının karşılandığı bir ortamda büyüyen çocuklar, sağlıklı ve mutlu bireyler olarak yetişirken, aksine istismar ve ihmal edilen, sevgi ve ilgiden yoksun olarak büyüyen çocuklarda ise bir takım davranışsal sorunlar gözlenmektedir (Yörükoğlu, 2007). Okul öncesi dönemde çocuğun gelişimi ve eğitiminde özellikle annelerinin önemli bir yeri vardır (Ulutaş Avcu, 2016).

Okul öncesi dönemde ebeveyniyle özdeşim kuran çocuk için, anne ve babanın davranış kalıpları önemli bir rol oynamakta ve çocuğun yaşamı boyunca edineceği kimlik kazanımı üzerinde etkili olmaktadır. 3-6 yaş arasında okul öncesi eğitime başlayan çocuk için okuldaki yaşantıları sonucu annesine olan bağl1lı̆̆ azalsa bile, annesinin ilgisi ve sevgisine ihtiyaç duymaktadır. Anne-çocuk arasında kurulan iletişimin niteliği, çocuğun ruhen ve bedenen sağlıklı olması açısından önem taşımaktadır. Anneler bu süreçte çocuğu disipline etmek için farklı yöntem ve teknikler kullanmaktadırlar. Kimi anneler farkında olarak ya da olmayarak çocuklara fiziksel ceza uygularken, kimi anneler sevdiği bir şeyden yoksun bırakarak, sözel şiddet uygulayarak ya da çocuğunu ihmal ederek disipline edebileceğini düşünmektedir. Annelerin sergiledikleri bu tutum ve davranışların bir kısmı istismar kategorisi içinde sınıflandırılmakta ve istismar kavramı ile ilgili literatürde birçok tanım yapılmaktadır. Dünya sağlık örgütü çocuk istismarını çocuğun sağlığını, fiziksel ve psikososyal gelişimini olumsuz yönde etkileyen bir yetişkinin bilerek veya bilmeyerek yaptığı davranışları çocuk istismarı olarak tanımlamaktadır (Dubowitz, 2005). Tanım aynı zamanda çocuğun istismar veya şiddet olarak algılamadığı veya yetişkinlerin istismar olarak kabul etmediği davranışları da içine almaktadır. Ayrıca istismar çocukların beden ve ruh sağlıklarına zarar veren ya da fiziksel, zihinsel, duyuşsal, sosyal ve ahlaki gelişimlerini engelleyen ve kaza sonucu olmayan eylemler olarak da ifade edilmektedir (Gürkaynak ve Gözütok, 1998; Kozcu, 1991; Lynch, 1991). İhmal ise, çocuğa bakmakla yükümlü ve/veya onu eğitmekle sorumlu olan kişilerin çocuğun bakım, beslenme, barınma, sevgi, güven, eğitim 
gibi temel gereksinimlerini karşılama konusundaki görevlerini gerektiği gibi yapmamaları olarak belirtilmektedir (Gürkaynak ve Gözütok, 1998; Lynch, 1991). Bir davranışın istismar ya da ihmal olarak kabul edilebilmesi için çocuk tarafından algılanması veya yetişkin tarafından bilinçli olarak yapılması bir koşul değildir (Polat, 2007). Çocuk istismarı fiziksel istismar, cinsel istismar, duygusal istismar ve ihmal olmak üzere dört gruba ayrılmaktadır. Fiziksel istismar en yaygın olan ve en kolay saptanan istismar türüdür. Çocuğa bir kez vurma ya da sürekliliği içermektedir. Tekmeleme, sarsma, ısırma, yakma, zehirleme, su altında tutma, diğer tehlikeli ve zararlı güç kullanımını ya da men etme (tuvalete kilitleme, sandalyeye bağlama vb.) davranışlarını içerebilir (Wekerle, Alec, David ve Carrie, 2006). Duygusal istismar çocuğun nitelik, kapasite ve arzularının devamlı olarak aşağılayıcı muameleye maruz bırakılması, korkutulması, tehdit edilmesi, yaşıyla ve gelişimsel durumuyla uygunsuz beklentilere hedef olması, toplumsal olarak kabul edilemez yöntemlerle yetiştirilmesi olarak tanımlanmaktadır (Atamer, 2005). Duygusal istismar ise, tek başına görülebildiği gibi fiziksel ve cinsel istismarla birlikte de görülebilmektedir. Ancak tek başına görüldüğü durumlarda fark edilmesi oldukça güçtür. Çünkü yara, yırtık gibi belirgin özellikler göstermez. Cinsel ya da fiziksel istismara uğramış bir çocuk, bunun uzantısı olarak duygusal istismara da maruz kalmaktadır (Çağdaş, 2002; Veltman ve Browne, 2000). Çocuk ve erişkin arasındaki temas ve ilişki, o erişkinin veya başka birinin seksüel uyarımı için kullanılmışsa çocuk cinsel olarak istismar edilmiş demektir (Gül Çelik, 2012). İhmal ve istismarı birbirinden ayıran en temel nokta istismarın aktif, ihmalin pasif bir olgu olmasıdır. İhmalin belirti ve bulguları, yasal tanımı istismara göre daha belirsizdir (Munkel, 1994).

Günümüzde çocuk istismarı ne yazık ki yoğun bir şekilde yaşanmaya devam etmektedir. Her tür sosyoekonomik ve eğitim düzeyindeki yetişkinlerin, çocuklara çeşitli istismar türlerini uyguladıkları bilgisi çeşitli kaynaklardan edinilmektedir. Alan yazın incelendiğinde ise çocuk istismarı ile ilgili birçok çalışma yapıldı̆̆ı görülmektedir. Öğretmenlerin çocuk istismarı konusundaki farkındalık düzeyleri (Aksel ve Yılmaz Irmak, 2015; Dereobalı, Çırak Karadağ ve Sönmez, 2013; Sağır, 2013; Tugay, 2008; Türk, 2010), aile içi istismar (Ateah ve Durrant; 2005; Finkelhor, Ormrod ve Turner, 2007) istismarın çocuk üzerindeki etkileri (Lynch, 1991; Sexton,1998; United Nations International Children's, 2010), yapılan çalışmalardan bazılarıdır. Günümüzde ise gerek sosyal medya gerekse diğer kaynaklardan edindiğimiz bilgiler, çocuklara yönelik istismar düzeyinin oldukça artış gösterdiği yönündedir. Bazı çalışmalarda çocuk istismarının, ileriki yaşamda yarattığı davranışsal etkiler üzerinde çalışılmıştır. Navalta, Polcari, Webster, Boghossian ve Teicher, 
(2006), psikolojik sorunları olan bir grup üzerinde yaptığı çalışmada, bu bireylerin çocukluk döneminde istismara maruz kaldıklarını belirlemişlerdir. Keser, Odabaş ve Elibüyük, (2010), tarafından yapılan bir araştırmada ise, çocukluk döneminde istismara uğramış anne ve babaların, kendi çocuklarına fiziksel şiddet uyguladıkları sonucuna ulaşmıştır. Bu bağlamda Corby'nın (2006) belirttiği üzere, çocuk istismarının neden meydana geldiğini anlamaya çalışmak, açıklanamaz gibi görünen olaylar üzerinde çalışanların kendilerini daha kontrollü hissetmesi, müdahale ve tedavi için yol gösterici olması ve bu alanda politika oluşturmaktan sorumlu olanları bilgilendirmesi gibi işlevlere katkıda bulunmakta ve çocuğu koruma anlamında atılacak adımlar için büyük katkı sağlamaktadır. Ayrıca yapılan çalışmalarda anne, baba ve ailenin diğer bireyleri bir arada ele alınmış, sadece annelerin istismar potansiyelleri üzerinde çalışılmamıştır. Bu nedenle, bu araştırmada annelerin istismar kapsamına giren davranışlarının ne derece farkında olduklarının belirlenmesi ve bazı değişkenlerle olan ilişkilerinin değerlendirilerek elde edilen sonuçların, ileride alınacak önleyici rehberlik hizmetlerine 1şık tutması amaçlanmıştır. Ayrıca istismara yönelik araştırmaların güncelliğini yitirmemesi amacıyla da çalışmanın alan yazınına kazandırılması hedeflenmiştir.

\section{Yöntem}

$\mathrm{Bu}$ bölümde araştırmanın deseni, çalışma grubu, veri toplama araçları ve verilerin analizi kısımlarına yer verilmiştir.

\section{Araştırmanın Deseni}

Araştırma, annelerin istismar potansiyellerinin farklı değişkenlerle olan ilişkisini incelemeyi amaçladığından çalışmada betimsel tarama modelinde ilişkisel tarama yöntemi kullanılmıştır. Çünkü tarama modelleri geçmişte ya da halen var olan bir durumu var olduğu şekli ile betimlemeyi amaç edinen araştırmalar için uygun bir modeldir. Betimsel tarama modelleri genel tarama ve örnek olay taramaları olarak iki bölüme ayrılmaktadır. İlişkisel tarama modeli genel tarama yöntemi içine giren bir yöntemdir. Genel tarama modelleri; çok sayıda elemandan oluşan bir evrende, evren hakkındaki genel yargıya varmak amacı ile evrenin tümü ya da ondan alınacak bir grup örnek ya da örneklem üzerinde yapılan tarama düzenlemeleridir (Karasar, 2012). Bu grup içinde yer alan ilişiksel tarama modelleri ise iki veya daha çok sayıdaki değişken arasında birlikte değişim varlığını ve/veya derecesini belirlemeyi amaçlayan araştırma modelleridir. İlişkisel tarama modelindeki betimlemeler (özelliklerin değerlerini belirleme işi) var olanın belli standartlara uyan ölçülerini bulmaya çalışmaktan çok, birey, nesne vb. durumlar arası ayrımların belirlenebilmesi amacına dönüktür (Cohen, Manion ve Morrison, 2000; Karasar, 2012). 


\section{Evren ve Örneklem}

Araştırmanın evrenini, Amasya ilinde yaşayan 4-6 yaş aralığında çocuğa sahip anneler oluşturmaktadır. Örneklemi ise Amasya ilinde, Milli Eğitim Bakanlığına bağlı bağımsız anaokullarına devam eden ve 4-6 yaş aralığında çocuğu bulunan 235 anne oluşturmaktadır. Örneklem seçiminde amaçlı örneklem yöntemlerinden, tipik durum örnekleme yöntemi kullanılmıştır. Örneklemin özelliği araştırma problemi ile ilgili olarak evrende yer alan çok sayıdaki durumdan tipik olan biriyle oluşturulmasıdır (Büyüköztürk, Çakmak Kılıç, Akgün, Karadeniz ve Demirel, 2011). Bu yöntemin örneklem seçiminde geneli yansitabileceği düşünülmektedir. Kısacası çalışma grubunun oluşturulmasında, 4-6 yaş aralığında çocuğa sahip, sıra dışı olmayan, ortalama düzeyde annelerin seçilmesi amaçlanmıştır. Çalışmaya katılan annelere ilişkin demografik özellikler Tablo 1'de sunulmuştur.

Tablo 1.

Çalışma grubunu oluşturan annelere ilişkin demografik özellikler

\begin{tabular}{llll}
\hline Değişkenler & Alt Kategoriler & $\mathrm{n}$ & $\%$ \\
\hline Çalışma Durumu & Çalışıyor & 156 & 66.4 \\
& Çalışmıyor & 79 & 33.6 \\
\hline Çocuk Sayısı & 1 çocuk & 108 & 46.0 \\
& 2 çocuk & 97 & 41.3 \\
& 3 çocuk & 24 & 10.2 \\
& 4 çocuk & 6 & 2.5 \\
\hline Çocuk Cinsiyeti & Kiz & 85 & 36.2 \\
& Erkek & 150 & 63.8 \\
\hline Yaş & $20-29$ & 48 & 20.3 \\
& $30-39$ & 133 & 56.6 \\
& $40-49$ & 47 & 20.0 \\
& $50-60$ & 7 & 3.1 \\
\hline Eŏgitim Durumu & İlköğretim & 49 & 20.9 \\
& Lise & 72 & 30.6 \\
& Üniversite & 114 & 48.5 \\
\hline
\end{tabular}


Tablo 1.de görüldüğü üzere, annelerin \% 64'ü çalışmakta, \% 46's1 tek çocuk sahibi, çocukların \% 63.8'i erkek, annelerin büyük bir kısmı \% 56.6'sı 30-39 yaş aralığında, \% 48.5'i ise üniversite mezunudur.

\section{Veri Toplama Araçları}

$\mathrm{Bu}$ araştırmada, annelerin çocuklarına yönelik istismar potansiyellerini ölçmek amacıyla araştırmacı tarafından geliştirilen İstismar Farkındalık Ölçeği-Ebeveyn Formu, kişisel bilgileri edinmek amacıyla da Kişisel Bilgi Formu kullanılmıştır.

İstismar Farkındalık Ölçeği-Ebeveyn Formu likert tipi olup beşli değerlendirmeden oluşmaktadır, "hiç katılmıyorum (1)", "katılmıyorum (2)", "kararsızım (3)", "katılıyorum (4)" ve "tamamen katılıyorum (5)" ifadelerini içermektedir. 18 maddeden oluşan ölçme aracı günlük rutinlerde ebeveynlerin çocuklara yönelik istismar potansiyellerini ölçmeyi amaçlamaktadır. Ölçme aracında yer alan maddeler çocuğa fiziksel ceza uygulama, çocuğun vücudunda yer alan darp izleri ile ilgili tutum, çocuğun istek ve ihtiyaçlarını görmezden gelme, çocuğun cinsellikle ilgili davranışlarında sergilenen tavırlar gibi durumları içermektedir. Ebeveyn formundan elde edilen puanın yüksek olması ebeveynlerin istismar potansiyellerinin yüksek olduğunu göstermektedir. Form ebeveynlere bireysel ya da gruplar halinde uygulanabilmektedir ve uygulaması yaklaşık on dakika sürmektedir. Ölçme aracının geçerliğini sağlamak amacıyla öncelikle kapsam geçerliği yapılmıştır. Kapsam geçerliği için alan yazın taraması ve ilgili ölçekler incelendikten sonra hazırlanan 25 madde okul öncesi eğitimi alanından 2, eğitim bilimleri alanından 2 ve Türkçe dil alanından 1 uzmanının görüşünü almak amacıyla sunulmuştur. Uzmanlar, ölçek maddelerinin istismarı ölçüp ölçmediğini, dilbilgisi yeterliğini ve anlaşılabilirliğini incelemişlerdir. Uzman görüşlerini değerlendirmek amacıyla Lawshe tekniği kullanılmıştır (Yurdugül, 2005). Lawshe tekniğinde uzmanların herhangi bir maddeye ilişkin görüşleri toplanarak kapsam geçerlik oranları elde edilir. "Kapsam geçerlik oranları (KGO), herhangi bir maddeye ilişkin “Gerekli” görüşünü belirten uzman sayılarının maddeye ilişkin görüş belirten toplam uzman sayısına oranının 1 eksiği ile elde edilir" (Yurdugül 2005, s.2).

Uzmanlar ölçme aracında yer alan tüm maddelere ilişkin "uygun” ifadesini kullanmışlardır. Dolayısıyla 5 uzmandan alınan görüşler doğrultusunda, maddelerin uygunluk düzeyi için KGO 1.00 olarak hesaplanmıştır. "Bu değer testteki tüm maddelerin gerekli olduğu ve kapsam geçerliğinin sağlandığı anlamına gelmektedir "(Yurdugül 2005, s.2). 
Daha sonra yapı geçerliğini belirlemek amacıyla Açımlayıcı Faktör Analizi (AFA) yöntemi kullanılmış ve tek faktör olarak yapılandırılan ölçme aracının toplam varyansın \%76'sını açıkladığı belirlenmiştir. Ölçme aracında yer alan 18 maddenin tek faktör altında toplandığ1 görülmüş ve ölçme aracındaki maddelerin yük değerleri ise .76 ve .93 arasında değişmektedir. Faktörlerin öz değerleri ve maddelerin faktör yüklerinin yüksek olması sebebiyle ölçme aracının geçerliğinin yüksek düzeyde olduğu söylenebilir.

Ölçme aracının güvenirliğini belirlemek amacıyla öncelikle Cronbach Alfa güvenirlik katsayısı hesaplanmış, kararlılığını ölçmek amacıyla da test tekrar test yöntemi uygulanmıştır. Güvenirlik için varimax rotasyon sonucu saptanan tek boyutlu ölçeğin tümü için Cronbach Alfa katsayıları (.98) olarak hesaplanmıştır. Ölçme aracının test tekrar test korelasyon değeri $\mathrm{r}=.94$ olarak bulunmuştur. $\mathrm{Bu}$ bulgular ölçme aracının geçerli ve güvenilir olduğunu göstermektedir. Kişisel bilgi formunda ise, annelerin yaşı, çalışma durumları, eğitim düzeyleri, çocuk sayıları ve çocuklarının cinsiyetine ilişkin bilgiler yer almaktadır.

\section{Verilerin Toplanması ve Analizi}

Verilerin toplanması için Amasya ili Milli Eğitim müdürlüğünden izin alındıktan sonra, 2016 Ocak tarihinde araştırmacı tarafından, İstismar Farkındalık Ölçeği-Ebeveyn Formu ve Kişisel Bilgi Formu, bağımsız anaokullarında görev yapan okul öncesi öğretmenlerine teslim edilmiş, öğretmenler de çocuklar aracılığıyla formları ailelere ulaştırmışlardır. 2016 Nisan ayında, 250 anneye ulaşan ve eksiksiz doldurulduğu belirlenen 235 ölçme aracı değerlendirmeye alınmıştır. Veriler SPPS 20.0 programına işlendikten sonra, analiz yapılmadan önce uç değerlerin olup olmadığına bakılmış ve regresyon analizinin “doğrusallık” ve “çok değişkenli normallik” varsayımlarının karşılandığı görülmüştür. Standardize edilmiş sapma değerler ile standardize edilmiş yordanan değerlerin grafiği doğrusallık varsayımının karşılandığını göstermektedir (Şekil 1). Standardize edilmiş sapma değerleri ile ilgili olarak çizilen, gözlenen ve beklenen birikimli olasılık dağılımı grafiğinde de normal dağılımdan önemli bir sapmanın olmadığı görülmektedir (Şekil 2). İstismar potansiyeli ile değişkenler arasında anlamlı bir ilişki olup olmadığına Pearson Korelasyon katsayısı, annelerin istismar potansiyellerinin yordayıcılarını belirlemek için "çoklu regresyon” analizi yapılmıştır. Bulgular .05 anlamlılık düzeyinde değerlendirilmiştir. 


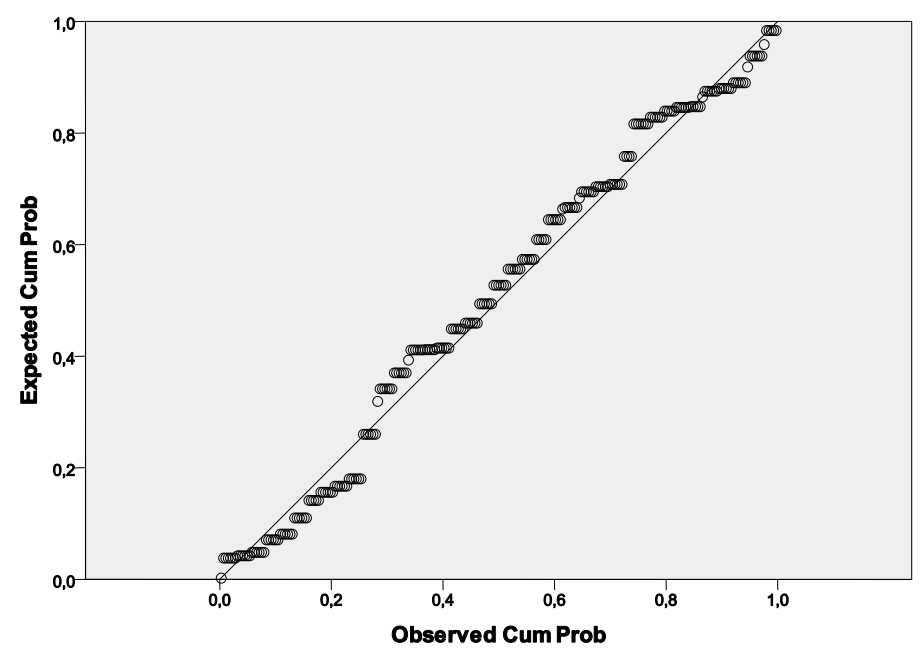

Şekil 1. Beklenen ve gözlenen birikimli olasılık

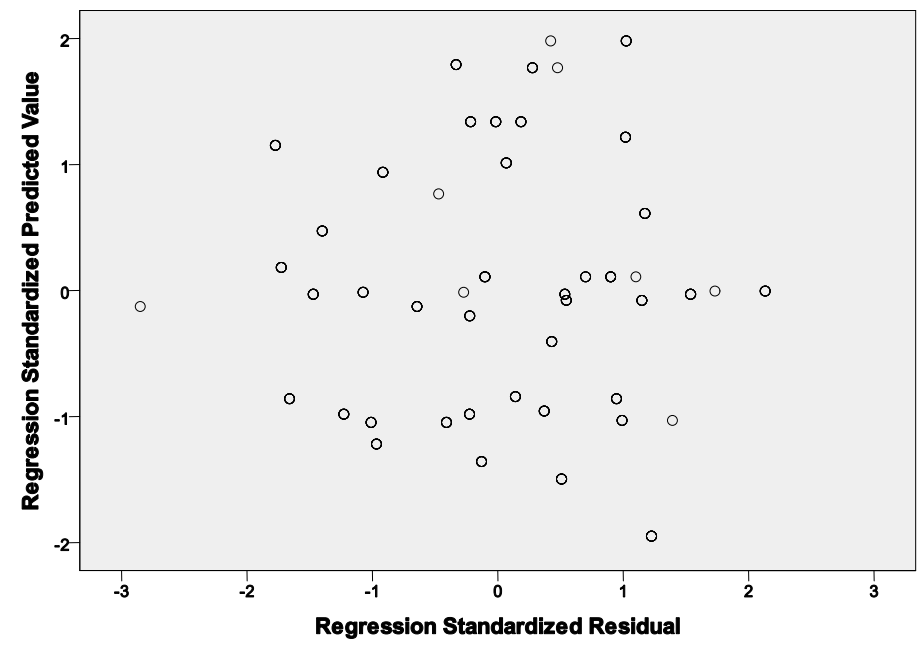

Şekil 2. Standardize tahmini değerler ve sapmalar

\section{Bulgular}

\section{Annelerin istismar potansiyellerine yönelik bulgular}

Annelerin istismar potansiyelleri ile diğer değişkenler arasındaki ilişkiyi belirlemek amacıyla pearson korelasyon katsayısına bakılmış ve bulgular Tablo 2.de sunulmuştur. 
Tablo 2

Annelerin istismar potansiyelleri ile diğer değişkenler arasındaki basit korelasyona ilişkin bulgular

\begin{tabular}{lllllll}
\hline Değişkenler & İ.P. & E. & Y. & Ç. & Ç.S. & Ç.C. \\
\hline İ.P. & 1 & & & & \\
\hline E. & .045 & 1 & & & & \\
\hline Y. & $-.152^{*}$ & .108 & 1 & & & \\
\hline Ç. & $\mathbf{- 1 3 8 ^ { * }}$ & $.262^{* *}$ & .055 & 1 & & \\
\hline Ç. S. & .034 & -.115 & $.594^{* *}$ & $.141^{*}$ & 1 & 1 \\
\hline Ç. C. & $.131^{*}$ & $.209^{* *}$ & -.028 & -.067 & $-.165^{*}$ & 1.63 \\
\hline Ort. & 56.37 & 2.27 & 2.05 & .663 & 1.69 & .481 \\
SS & 5.09 & .787 & .722 & .473 & .756 & \\
\hline
\end{tabular}

İstismar potansiyeli: İ.P. Eğitim: E Yaş: Y Çalışma: Ç Çocuk Sayısı: Ç.S. Çocuk Cinsiyeti: Ç.C. ${ }^{*} p<.05,{ }^{* *} p<.01$

Tablo 2'de basit korelasyon katsayılarından görüldüğü gibi, istismar ile annelerin yaşı $\left(\mathrm{r}=-.152^{*}\right)$, çalışma durumları $\left(\mathrm{r}=-138^{*}\right)$ ve çocukların cinsiyetleri arasında $\left(\mathrm{r}=.131^{*}\right), p<.05$ düzeyinde anlamlı ilişki olduğu görülmektedir.

\section{Annelerin İstismar Potansiyellerini Yordayan Değişkenlere Yönelik Bulgular}

Annelerin istismar potansiyellerini yordayan değişkenleri belirlemek amaciyla çoklu regresyon analizi yapılmıştır. Regresyon eşitliğine istismar bağımlı değişken olarak, annelerin eğitim düzeyi, yaşları, çalışma durumları, çocuk sayıları ve çocukların cinsiyetleri ise bağımsız değişken olarak alınmıştır. Sonuçlar Tablo 3’te sunulmuştur.

Tablo 3

Annelerin istismar potansiyellerine ilişkin çoklu regresyon bulguları

\begin{tabular}{llllll}
\hline Değişken & $\mathrm{B}$ & $\mathrm{S} . \mathrm{H}$. & $\beta$ & $\mathrm{T}$ & $\mathrm{P}$ \\
\hline Sabit & 52.644 & 1.735 & & 30.348 & .000 \\
\hline Ĕ̆t. Düz. & .239 & .457 & .037 & .523 & .601 \\
\hline Yaş & $\mathbf{1 . 2 3 3}$ & $\mathbf{. 5 7 8}$ & $\mathbf{. 1 7 5}$ & $\mathbf{2 . 1 3 4}$ & $\mathbf{. 0 3 4}$ \\
\hline Çalışma & $\mathbf{- 1 . 5 6 7}$ & $\mathbf{. 7 3 3}$ & $\mathbf{- . 1 4 6}$ & $\mathbf{- 2 . 1 3 9}$ & $\mathbf{. 0 3 6}$ \\
\hline Çocuk Say. & -.177 & .565 & -.026 & -.313 & .755 \\
\hline Çocuk Cin. & 1.213 & .704 & .037 & .523 & .601 \\
\hline $\mathrm{R}=.250 \mathrm{R}^{2}=0.063$ & & & & \\
$\mathrm{~F}=3.056 p=.011$ & & & & \\
\hline
\end{tabular}


Regresyon modeli istatistiksel olarak anlamlıdır $(p=.011)$ ve regresyon analizinden elde edilen bulgular annelerin eğitim düzeyi, yaşları, çalışma durumları, çocuk sayıları ve sahip oldukları çocukların cinsiyetlerinin doğrusal kombinasyonunun annelerin istismar potansiyellerini anlamlı bir düzeyde yordadığını göstermiştir $\left(R^{2}=.063, \mathrm{~F}=3.056, p<.05\right)$. Regresyon denklemine giren değerler açısından annelerin yaşı $\beta=.175, t=2.134, p<.05$ ) ve çalışma durumlarının $(\beta=-.146 \mathrm{t}=-2.139, p<.05)$ istismar potansiyelini yordama da anlamlı olduğu görülmüştür. Sonuç olarak annelerin istismar potansiyellerini etkileyen değişkenlerin yaş ve çalışma durumları olduğu söylenebilir.

\section{Tartışma ve Sonuç}

Bu çalışmada 4-6 yaş çocuğa sahip annelerin istismar potansiyellerinin çeşitli değişkenlerle olan ilişkisi incelenmiştir. Annelerin istismar potansiyellerini yordayan değişkenlere yönelik bulgular incelendiğinde, şu sonuçlara ulaşılmıştır: annelerin yaşı ve çalışma durumlarına ilişkin değerlerin annelerin istismar potansiyellerini yordama da anlamlı olduğu görülmüştür. Kısacası annelerin istismar potansiyelleri, yaş ve çalışma durumu ile ilişkilidir. Annelerin yaşı arttıkça çocuklara uyguladıkları istismar potansiyeli oranı azalmakta ve çalışan annelerin çocuklarını daha az istismar ettiği görülmektedir. Yaş ilerledikçe anneler deneyim kazanmakta, çocuk yetiştirme tutumları olumlu yönde gelişmektedir. Çalışan anneler ise aile ekonomisine katkıda bulunmakta ve buna bağlı olarak ailenin sosyoekonomik durumu gelişmekte, azalan stres ve kaygı durumuna bağlı olarak annelerin istismar potansiyelleri azalış göstermektedir. Yapılan bir çok araştırmada çocuğun aile içerisinde istismara maruz kalma şekli ve bu süreçten etkilenme biçimlerinin bir çok değişkenle ilişkili olduğu yönündedir.

Korelasyon bulguları incelendiğinde annelerin yaşı ile istismar potansiyelleri arasında negatif yönde, anlamlı bir ilişki olduğu görülmektedir. Annelerin yaşı ilerledikçe, çocuklarına uyguladıkları istismar düzeyi azalmaktadır. Yapılan bazı araştırmalar bu bulguları desteklemektedir. Güler, Uzun, Boztaş ve Aydoğan (2002) yılında yaptıkları araştırmada 2535 yaş aralığındaki annelerin çocuklarına daha fazla istismar uyguladıklarını belirtmişlerdir. Çalışmanın başka bir bulgusu da annelerin eğitim düzeyi ile istismar potansiyeli arasındaki negatif yönlü, anlamlı olan ilişkidir. Çalışan annelerin, çalışmayan annelere göre çocuklarına uyguladıkları istismar potansiyeli düzeyi azalmaktadır. Yapılan araştırmalar (İzmirli, Sur ve Polat, 2000; Murry, Baker ve Lewin, 2000; Öncü, Kurt, Esenay ve Özer, 2012; Polat, 2000) annelerin istismar potansiyellerindeki en önemli risk faktörünün ekonomik sıkıntılar olduğunu göstermektedir. Çalışmayan anne, evin diğer işleri ve çocuklarla ilgilenmek zorundadır, 
özellikle aile içinde evin gereksinimlerini ve bütçe ayarlamalarını yapmak zorunda olduğundan sıkıntıya düşmekte ve bu durum olumsuz davranışlar olarak çocuğa yansımaktadır. Çocukların cinsiyetleri ile annelerin istismar potansiyelleri arasında da pozitif yönde anlamlı bir ilişki bulunduğu görülmektedir. Bulgular kız çocuklarının anneleri tarafından daha çok istismara uğradığını göstermektedir. Öncü ve diğerleri (2012) araştırmalarında, kız çocuklarının aile içerisinde en fazla istismara uğrayan birey olduklarını belirlemişlerdir. Benzer şekilde Sunday ve diğerleri (2008), istismar oranının en çok kız çocuklarına yönelik olduğunu yaptıkları çalışmada belirtmişlerdir. Çünkü kız çocukları, erkek çocuklarına göre daha sessiz ve tepkisiz kalabilmektedir ve bu durumda istismar potansiyeli düzeyinin artmasında etkili olabilmektedir. Çocuk istismarı ile ilgili risk faktörleri incelendiğinde, alan yazında konuya ilişsin çeşitli ortak bulguların ortaya konulduğu görülmektedir. Özellikle çocuğun cinsiyeti (Altuntaş, 2013; Douglas, 2014; İmren, Ayaza, Yusufoğlu ve Arman, 2013; Soylu, Alpaslan, Ayaz, Esenyel ve Oruç, 2013) düşük sosyoekonomik düzey (Altıparmak, Yıldırım, Yardımcı ve Ergin, 2013; Öncü ve diğerleri, 2012) anne babanın çocukluk döneminde istismara maruz kalmış olmaları (Ayaz, Yılmaz Özpolat, Yücel ve Altunöz, 2013) ve ailede şiddet söz konusu olduğunda çocuklardan sonra en çok annelerin istismar ve şiddete maruz kalmaları (UNICEF, 2010) ilgili alan yazında en sık rastlanan bulgulardır. Çalışmalar ilgili araştırmayı destekler niteliktedir.

\section{Öneriler}

Araştırmadan elde edilen sonuçlar, annelerin istismar potansiyellerinin annelerin yaşı, çalışma durumları ve çocukların cinsiyetleri ile ilişkili olduğu yönündedir. Bu doğrultuda şu önerilerde bulunmak mümkündür:

- Benzer bir çalışma farklı örneklem grupları üzerinde yapılabilir.

- Babaların çocuk istismarı potansiyelleri, çeşitli değişkenler açısından ele alınıp incelenebilir.

- Ailelerin ve öğretmenlerin çocuk istismarı potansiyellerine yönelik farkındalık düzeylerini geliştirmek amacıyla, farklı istismar türlerini ele alan, birbirine paralel ölçme araçları geliştirilebilir.

- İstismar potansiyeli olan anne ve babaların istismar ve ihmal düzeyleri tespit edilerek, çocukluk yaşantıları ele alınarak, istismarın altında yatan nedenler araştırılabilir, bu yönde nitel ve nicel çalışmaların bir arada yapıldı̆̆ 1 karma desen çalışmalar yapılabilir. 


\section{Kaynakça}

Aksel, Ş. ve Yılmaz Irmak, T. (2015). Çocuk cinsel istismarı konusunda öğretmenlerin bilgi ve deneyimleri. Ege Ĕgitim Dergisi (16) 2, 373-391.

Altıparmak, S., Yıldırım, G., Yardımcı, F. ve Ergin, D. (2013). Annelerden alınan bilgilerle çocuk istismarı ve etkileyen etkenler. Anadolu Psikiyatri Dergisi, 14, 354-361.

Altuntaş, S. (2013). Lise son sınıf öğrencilerinin çocukluk çă̆ı örselenme yaşantıları ile mesleki olgunluk düzeyleri arasındaki ilişkinin incelenmesi. (Yayımlanmamış Yüksek Lisans Tezi). Atatürk Üniversitesi, Eğitim Bilimleri Enstitüsü, Erzurum.

Atamer A. (2005). Çocuk İstismarı tarama anketi: Geliştirme, geçerlilik ve güvenirlilik çalışması. (Yayımlanmamış Doktora Tezi). İstanbul Üniversitesi, Adli Tıp Enstitüsü, İstanbul.

Ateah, C.A. ve Durrant, J.E., (2005). Maternal use of physical punishment in response to child misbehavior: Implications for child abuse prevention. Child Abuse \& Neglect, 29, 169- 185.

Ayaz, T., Yılmaz Özpolat, A., Yücel, D. ve Altunöz, U. (2013). Kendi çocuğunu fiziksel olarak istismar eden ve kendisi de fiziksel istismar gören bir OKB vakası. Bilişsel Davranışçı Psikoterapi ve Araştırmalar Dergisi, 2, 116-120.

Büyüköztürk, Ş., Kılıç Çakmak, E., Akgün, Ö. E. , Karadeniz, Ş., ve Demirel, F. (2012). Bilimsel araştırma yöntemleri. Ankara: Pegem A.

Cohen, L., Manion, L. ve Morrison, K. (2000). Research methods in education. London New York: Routledge Falmer.

Corby, B. (2006). Child abuse: Towards a knowledge base. New York: Open University Press.

Çağdaş S. (2002). Çalışan çocukların hakları. (Yayımlanmamış Yüksek Lisans Tezi). İstanbul Üniversitesi, Sağlık Bilimleri Enstitüsü, İstanbul.

Dereobalı, N., Çırak Karadağ, S. ve Sönmez, S. (2013). Okul öncesi eğitim öğretmenlerinin çocuk istismarı, ihmali, şiddet ve eğitimcilerin rolü konusundaki görüşleri. Ege Eğitim Dergisi. 14 (1). 50-66

Dubowitz , H. (2005). Preventing child neglect and physical abuse. Pediatr Rev, 23, 191 196.

Douglas, E. M. (2014). A comparison of child fatalities by physical abuse versus neglect: Child, family, service and worker characteristics. Journal of Social Service Research, 40, 259-273.

Finkelhor, D., Ormrod, R.K., ve Turner, H.A. (2007). Re-Victimization patterns in a national longitudinal sample of children and youth. Child Abuse \& Neglect, 31, 479502. 
Gül Çelik, G. (2012). Sexual abuse in a classroom of ten male students: A group victimization. Journal of child sexual abuse, 21, 543-552.

Güler, N., Uzun, S., Boztaş, Z. ve Aydoğan, S. (2002). Anneleri tarafindan çocuklara uygulanan duygusal ve fiziksel istismar/ihmal davranışı ve bunu etkileyen faktörler. Cumhuriyet Üniversitesi Tip Fakültesi Dergisi, 24(3), 128-134.

Gürkaynak, İ. ve Gözütok, D. (1998). Yurttaş olmak için. İstanbul: Umut.

İmren, S. G., Ayaza, A. B., Yusufoğlu, C., ve Arman, A. R. (2013). Cinsel istismara uğrayan çocuk ve ergenlerde klinik özellikler ve intihar girişimi ile ilişkili risk etmenleri. Marmara Medical Journal.. 26, 11-16

İzmirli M, Sur H ve Polat N. (2000). Çocuğa karşı dayak olgusu ve çocuk istismarı. Çocuk Forumu Dergisi, 3(1), 37-49.

Karasar, N. (2012). Bilimsel araştırma yöntemi. Ankara: Nobel.

Keser, N., Odabaş, E., ve Elibüyük, S. (2010). Ana-babaların çocuk istismarı ve ihmali konusundaki bilgi düzeylerinin incelenmesi. Türkiye Çocuk Hastalıkları Dergisi, 4(3), 150-157.

Kozcu, Ş. (1991). Çocuk istismarı ve ihmali, aile yazıları 3. Başbakanlık Aile Araştırma Kurumu Bilim Serisi, 5(3), 379-390.

Lynch M.(1991). Çocuk istismarı ve ihmali. Çocukların Kötü Muameleden Korunması I.Ulusal Kongresi Kitabı.

Munkel WI .(1994). Neglect and abandonmet. Child maltreatment GW medical Publishing: St. Louis.

Murry, SK., Baker. AW., ve Lewin L.(2000). Screening families with young children for child maltreatment potantial. Pediatric Nursing, 26(1), 47-54.

Navalta, CP., Polcari, A., Webster, DM., Boghossian, A.,ve Teicher, MH. (2006). Effects of childhood sexual abuse on neuropsychological and cognitive function in college women. J Neuropshiatry Clin Neurosci, 18(1),45-53.

Öncü, E., Kurt, A. Ö., ve Esenay, F. I. (2012). Çalışan çocukların ailede istismarı. Türkiye Halk Să̆lı̆̆ Dergisi, 10(3), 128-140.

Polat O. (2000). Adli tıp. İstanbul: Der.

Polat, O. (2007). Tüm boyutlarıyla çocuk istismarı: Tanımlar I. Ankara: Seçkin.

Sağır, M. (2013). Okul öncesi ve sınıf öğretmenlerinin çocuk istismarl ve ihmaline yönelik görüşleri ve farkındalık düzeyleri. (Yayımlanmamış Yüksek Lisans Tezi). Erciyes Üniversitesi, Eğitim Bilimleri Enstitüsü, Kayseri. 
Sexton, E. T. (1998). Harmed children: Delinquency, child abuse and school. Reclaiming Children and Youth, 7, 95-99.

Soylu, N., Alpaslan, A. H., Ayaz, M., Esenyel, S., ve Oruç, M. (2013). Psychiatric disorders and characteristics of abuse in sexually abused children and adolescents with and without intellectual disabilities. Research in Developmental Disabilities, 34, 43344342.

Sunday, S., Labruna, V., Kaplan, S., Pelcovitz, D., Newman, J., ve Salzinger, S. (2008). Physical abuse during adolescence: Gender differences in the adolescents' perceptions of family functioning and parenting. Child Abuse and Neglect, 32, 518.

Tugay, D. (2008). Öğretmenlerin çocuk istismarı ve ihmaline yönelik farkındalık düzeyleri. (Yayımlanmamış Yüksek Lisans tezi). Marmara Üniversitesi, Sağlık Bilimleri Enstitüsü, İstanbul

Tunca, T. (2012). Türkiye’de değişen aile ve çocuğa yüklenen anlamlar. içinde Adak, N. (Ed.). Değişen Toplumda Değişen Aile (s. 163-176). Ankara: Siyasal.

Türk, S. (2010). Öğretmen adayları ile ilkögretim okullarında görev yapan öğretmenlerin çocuk istismarı potansiyeli açısından incelenmesi. (Yayımlanmamış Yüksek Lisans Tezi). Zonguldak Karaelmas Üniversitesi, Sosyal Bilimleri Enstitüsü, Zonguldak.

Ulutaş Avcu, A. (2016). Annelerin beş yaş çocuklarının gelişimine ilişkin okul öncesi eğitimden beklentilerinin incelenmesi. Cumhuriyet International Journal of Education (5) 2, 23-32.

UNICEF, (2010). Türkiye'de çocuk istismarı ve aile içi şiddet araştırması özet raporu. http://www.unicef.org.tr/files/bilgimerkezi/doc/cocuk-istismari-raporu-tr.pdf adresinden elde edildi.

Veltman, M.W.M. ve Browne, K.D. (2000). Pictures in the classroom can teacher and mental health proffessionals identify maltreated children's drawings?. Child Abuse Review, 9, 328-336.

Wekerle, C., Alec L. M., David A. W.,ve Carrie B. S. (2006). Childhood maltreatment .USA: Hogrefe and Huber Publishers.

Yörükoğlu, A. (2007). Değişen toplumda aile ve çocuk. İstanbul: Özgür.

Yurdugül, H. (2005, Eylül). Ölçek geliştirme çalışmalarında kapsam geçerlikleri için kapsam geçerlik indekslerinin kullanılması. XIV Ulusal Eğitim Bilimleri Kongresinde Sunulmuş Bildiri, Pamukkale Üniversitesi, Denizli.

Zeybekoğlu Dündar, Ö. (2012). Değişen ve değişsemeyen yönleriyle aile: Yapısl, türleri ve işlevleri, değişen toplumda değişen aile sosyolojik tartışmalar. Ankara: Siyas 


\section{Extended Abstract}

Unfortunately, child abuse continues intensively, nowadays. According to the different sources, it can be said that, children are abused by the adults from every levels of socioeconomic and educational status. There are many related studies in recent studies such as teachers’ awareness levels of child abuse (Sağır, 2013, Tugay, 2008; Türk, 2010), domestic violence (Ateah ve Durrant; 2005; Finkelhor, Ormrod ve Turner, 2007), the effects of abuse on children (Altıparmak, Yıldırım, Yardımcı ve Ergin, 2013; Lynch, 1991; Sexton, 1998; UNICEF, 2010). According to the Corby (2006) trying to understand the reasons of child abuse ensures the researchers who study on the unexplainable things, to feel cooler; some tips on intervention and treatment; to inform the policymakers who study on this area. And finally it ensures some important supports to protect the child. In the present study, it was aimed to investigate the relations between abuse behaviors of mothers and some different variables.

In this study, relational scanning model (survey), a quantitative research approaches, was used. This model (survey) aims to measure whether or not two or more variables tend to change together in the same time period. In this respect, the aim of survey technique was to observe all situations in its true colors (Karasar, 2012).

The population of this study consists of mothers who live in Amasya province and also have children aged between the ages of 4 and 6. The sample of this study consists of 235 mothers whose children are attending a public kindergarten in Amasya province. Typical Case Sampling method was used. This sampling method ensures to have more distinctive samples in the edge of main question of a research (Büyüköztürk, Çakmak Kılıç, Akgün, Karadeniz ve Demirel, 2011). 64 \% of mothers were employed; $46 \%$ of mothers had only one child; 63.8 \% of children were boys; $56.6 \%$ of mothers aged between 30 and 39; $48.5 \%$ of mothers were university graduate.

Abuse Awareness Scale-Parent Form developed by the researcher was used to determine parents' potentials of child abuse and also Personal Information Form was used in order to gain personal information about mothers. Parent form is a likert scale which has 18 items in order to assess parents' levels of abuse towards their children in daily routines. One factored scale's (as a result of varimax rotation) Cronbach Alpha coefficient is .98. Test-retest correlation is found as .94 . According to these results scale is reliable and valid. Information about mothers' ages, employment status, educational status, number of children and gender of their children were gathered by Personal Information Form. 
Abuse Awareness Scale-Parent Form and Personal Information Form were administered to 250 mothers and among these 235 correctly and totally filled forms were considered for analysis. Before analyzing the data, extreme values, linearity and multivariate normal distribution assumptions were checked. Figures of standardized deviation values and standardized predicted values also showed that these assumptions were assumed (see Figure 1). Chart of observed and expected values, drawn according to standardized deviation values showed that there was no important wrap according to the normal distribution (see Figure 2). Pearson Correlation coefficient was used to examine the relationship between potentials of abuse and variables; Multiple Regression Analysis was used to determine the predictors of mothers' potentials of abuse.

The correlations between mothers' (who have 4-6 aged children) potentials of abuse and different variables were investigated in this study. Mothers' age $(\beta=.175, \mathrm{t}=2.134, p<.05)$ and employment status $(\beta=-.146 \mathrm{t}=-2.139, p<.05)$ predicted significantly the mothers' potentials of abuse. According to the results, there was a negative but significant correlation between mothers' age and potentials of abuse $(r=-.152, p<.05)$. Negative but significant correlation was found between mothers' educational status and potentials of abuse, as the other finding of this study $(\mathrm{r}=-.138, p<.05)$. It was found that, unemployed mothers abuse their children more than employed mothers. A significant correlation was found between the gender of children and abuse by mothers $(\mathrm{r}=.131, p<.05)$. Results showed that girls were more abused than boys by their mothers. Considering these findings of this study, some suggestions are provided. First, a similar study may be studied with various samples. Second, fathers' potantials of child abuse may be investigated according to different variables and some parallel assessment tools address different kind of abuse may be developed in order to improve fathers' levels of awareness of child abuse. Third, mixed method studies which combine qualitative and quantitative studies may be studied in order to determine the abusing parents' levels of awareness of child abuse/neglect and to investigate the roots of abuse and neglect by addressing childhood years experiences. 